OPEN ACCESS

Edited by: Pablo Pelegrin,

Instituto Murciano de Investigación

Biosanitaria, Spain

Reviewed by:

Christian Michael Hedrich,

University of Liverpool,

United Kingdom

Albrecht Pliper,

Universitätsklinikum Frankfurt,

Germany

${ }^{*}$ Correspondence:

Rubén Francés

frances_rub@gva.es

Specialty section:

This article was submitted

to Inflammation,

a section of the journal

Frontiers in Immunology

Received: 21 March 2018

Accepted: 08 May 2018

Published: 28 May 2018

Citation:

Caparrós E and Francés R (2018)

The Interleukin-20 Cytokine

Family in Liver Disease.

Front. Immunol. 9:1155.

doi: 10.3389/fimmu.2018.01155

\section{The Interleukin-20 Cytokine Family in Liver Disease}

\author{
Esther Caparrós ${ }^{1,2}$ and Rubén Francés ${ }^{1,2,3 *}$ \\ 'Departamento de Medicina Clínica, Universidad Miguel Hernández, San Juan de Alicante, Spain, ${ }^{2}$ Instituto ISABIAL- \\ FISABIO, Hospital General Universitario de Alicante, Alicante, Spain, ${ }^{3}$ CIBERehd, Instituto de Salud Carlos III, Madrid, Spain
}

The three main causes of inflammation and chronic injury in the liver are viral hepatitis, alcohol consumption, and non-alcoholic steatohepatitis, all of which can lead to liver fibrosis, cirrhosis, and hepatocellular carcinoma, which in turn may prompt the need for liver transplant. The interleukin (IL)-20 is a subfamily part of the IL-10 family of cytokines that helps the liver respond to damage and disease, they participate in the control of tissue homeostasis, and in the immunological responses developed in this organ. The best-studied member of the family in inflammatory balance of the liver is the IL-22 cytokine, which on the one hand may have a protective role in fibrosis progression but on the other may induce liver tissue susceptibility in hepatocellular carcinoma development. Other members of the family might also carry out this dual function, as some of them share IL receptor subunits and signal through common intracellular pathways. Investigators are starting to consider the potential for targeting IL-20 subfamily members in liver disease. The recently explored role of miRNA in the transcriptional regulation of IL-22 and IL-24 opens the door to promising new approaches for controlling the local immune response and limiting organ injury. The IL-20RA cytokine receptor has also been classified as being under miRNA control in non-alcoholic steatohepatitis. Moreover, researchers have proposed combining anti-inflammatory drugs with IL-22 as a hepatoprotective IL for alcoholic liver disease (ALD) treatment, and clinical trials of ILS for managing severe alcoholic-derived liver degeneration are ongoing. In this review, we focus on exploring the role of the IL-20 subfamily of cytokines in viral hepatitis, ALD, non-alcoholic steatohepatitis, and hepatocellular carcinoma, as well as delineating the main strategies explored so far in terms of therapeutic possibilities of the IL-20 subfamily of cytokines in liver disease.

\section{Keywords: interleukin-20 family, viral hepatitis, alcoholic liver disease, non-alcoholic liver disease, hepatocellular carcinoma \\ THE INTERLEUKIN (IL)-20 CYTOKINE FAMILY: MOLECULAR FEATURES AND ROLE IN DISEASE}

The IL-20 subfamily of cytokines represents one of the three subfamily groups comprising the IL-10 family of cytokines. This family also includes the IL-10 cytokine itself and the type III IFN group (with IL-28A, IL-28B, and IL-29 members), categorized according to their biological function (1). They all work together to maintain epithelial tissue homeostasis and integrity, enhancing innate epithelial immunity, and regulating the healing process after infection or inflammatory events (2-4). The IL-20 subfamily includes IL-19, IL-20, IL-22, IL-24, and IL-26, which all have the common 
function of communicating leukocytes and epithelial cells in different tissues such as the liver. They play an important role in controlling tissue regeneration following injury, promoting survival as well as inhibiting apoptosis of epithelial cells (5).

The IL-20 subfamily of cytokines is encoded by genes located in different clusters, which all share genomic organization, primary and secondary structures, and receptor complexes (6). IL-19, -20, and -24 genes are confined in chromosome 1q32, close to IL-10 gene location (7), while IL-22 and IL-26 are enclosed in chromosome 12q16 $(8,9)$ (Figure 1A). Regarding their regulation, different transcription factors have been reported for IL-19 (PE1 and AML-1) (10), IL-20 (NF-кB) (11), and IL-24 (Jak1, Stat3, Stat6, Spcs3, and AP-1) $(12,13)$, though only putative regulators have been suggested for IL-22 and IL-26 transcriptional control. Signaling events by IL-20 subfamily members result in receptor dimerization; Janus kinase (Jak) 1, Jak2, and Tyrosine kinase 2 phosphorylation; and final signal transducer and activator of transcription (STAT)1 STAT3, and STAT5 activation (14-17) (Figure 1B). The best-studied cytokine signaling pathways are those regulated by IL-10 and IL-22, with the mitogen-activated protein kinases' final recruitment for anti-apoptotic and mitogenic gene expression in target cells.

Cellular sources of the IL-20 subfamily of cytokines include monocytes, macrophages (18-20), dendritic cells (DCs) (21-23), B-cells (22), Thelper (Th) 2 and Th17 cells, cytotoxic CD8+ T cells, natural-killer (NK) cells, innate lymphoid cell (ILC) 3 (4, 24-36), fibroblasts (37), NKT cells (38-40), and $\gamma \delta$ T cells (41-43) to epithelial cells $(12,44-48)$ (Figure 1B). They regulate new cytokine secretion according to their cellular targets which are immune system cells, such as monocytes, DCs, neutrophils or T cells (16), and also hepatocytes $(2,49)$, acinar cells $(50)$, fibroblasts, epithelial cells (51-53), keratinocytes (54), or adipocytes $(4,55)$.

In the liver, the IL-20 cytokine subfamily has a key role in inflammatory pathological processes. The best-studied member of the family in liver homeostasis is the IL-22 cytokine. In a mouse model, it has been shown to lessen metabolic syndrome-a condition related to chronic low-level inflammation-by inducing the activation and expression of lipogenesis-related genes and helping with the triglyceride and cholesterol metabolism (56). IL-22 also prevents apoptosis of hepatic stellate cells and attenuates liver fibrosis in mice $(57,58)$ and rat models $(59)$, and reported as a predictive severity marker in advanced stages of liver cirrhosis (60). Due to its hepatoprotective and anti-fibrotic properties, different studies have proposed IL-22 as a plausible candidate in the treatment of alcoholic liver disease (ALD) $(61,62)$. Commensal bacteria, such as Lactobacillus, have been shown to induce the production of IL-22 by gut ILCs. Rising IL-22 levels provoke the recruitment of regulatory DCs into the liver, constricting the hepatic inflammatory response, and favoring a tolerant tissue microenvironment (63). It is still unknown whether the protective role attributed to IL-22 is unique or shared with other IL-20 family members, but IL-19, IL-20, and IL-24 may also function as protective cytokines during liver inflammation (3), as they all share signaling pathways through the IL-20R2 receptor subunit, which is greatly induced during LPS liver challenge (64). IL-20 and IL-24 can also signal through heterodimeric receptor formation with IL-22RA1, which could entail some redundancy in their action. Both cytokines participate in lipid metabolism regulation, although they have failed to improve metabolic disorder in obese mice (65). Also, IL-19, IL-22, and IL-24 participate in wound healing (66-69), an event present not only in the skin but also in liver disease as a first step for fibrogenesis, cirrhosis, and liver failure (70). IL-22 also induces the expression of vascular entothelial growth factor A, which facilitates angiogenesis and neo-vacularization during wound healing (66). IL-24 improves resolution of Salmonella typhimurium infection when exogenously administered to mice (71), a quality not confirmed up to now for the IL-20 cytokine. Furthermore, IL-24 has been shown to inhibit hepatoma cell growth in the mouse model (10). Finally, IL-26 has antimicrobial and antiviral functions $(72,73)$. Its role in liver disease is mainly limited to hepatitis $\mathrm{C}$ virus (HCV) infection, although it is also implicated in liver fibrosis, as shown in a mouse model of obliterative bronchiolitis (74). IL-26 is overexpressed in $\mathrm{HCV}$ infection, inducing an antiviral state and endowing NK cells with a higher killing capacity over HCV-infected cells (75). IL-26 also targets epithelial cells, probably favoring a better cutaneous and mucosal immunity (76). Table 1 summarizes the functions of the IL-20 subfamily of cytokines in liver disease.

\section{IL-20 CYTOKINE FAMILY IN VIRAL HEPATITIS}

Hepatitis $\mathrm{B}$ virus (HBV) and $\mathrm{HCV}$ are the most frequent virus types that induce chronic or acute and chronic forms of hepatitis, respectively. In patients, there is an increase in the number of cells producing IL-22 in both HBV and HCV (98-100). Furthermore, there is an increase in the number of liver progenitor cells in infected mice, a finding that has been corroborated in patients with chronic HBV (79). IL-22 production in HBV-infected patients seems to be under Notch pathway control. Experiments performed in a mouse model in vivo with Notch signaling inhibitors show that IL-22 was clearly diminished in the liver (101). It has also been reported to promote the modulation of the immune response during viral infection by downregulating the S100 family of viral proteins (77). Nevertheless, a dual role in protection and inflammation induction has been proposed for IL-22 in chronic HBV infection, either promoting cell proliferation and improving fibrosis, or inducing chemokine production and neutrophil recruitment (78). More recently, different controversial roles have emerged for IL-22 in viral infection. For example, IL-22 has been associated with liver fibrosis severity in patients infected with $\operatorname{HCV}(82,83)$, with a possible pathological role residing in the accumulation of IL-22 in fibrotic areas due to its role in ameliorating liver tissue damage (85). In this sense, Sertorio et al. found that IL-22 functions as a protective factor, while IL-22 binding protein, a natural protein antagonist for IL-22, contributes to worsening liver fibrosis in chronic HCV infection (84). On the other hand, Zhao et al. attributes a pathogenic role to IL-22 because of its participation in promoting Th17 recruitment in chronic liver inflammation and fibrosis in HBV infection (80), Zhang et al. postulates that IL-22 works as a proinflammatory cytokine in response to HBV (81), and Gao et al. raise the possibility that the inflammatory tissue milieu represents different 
A

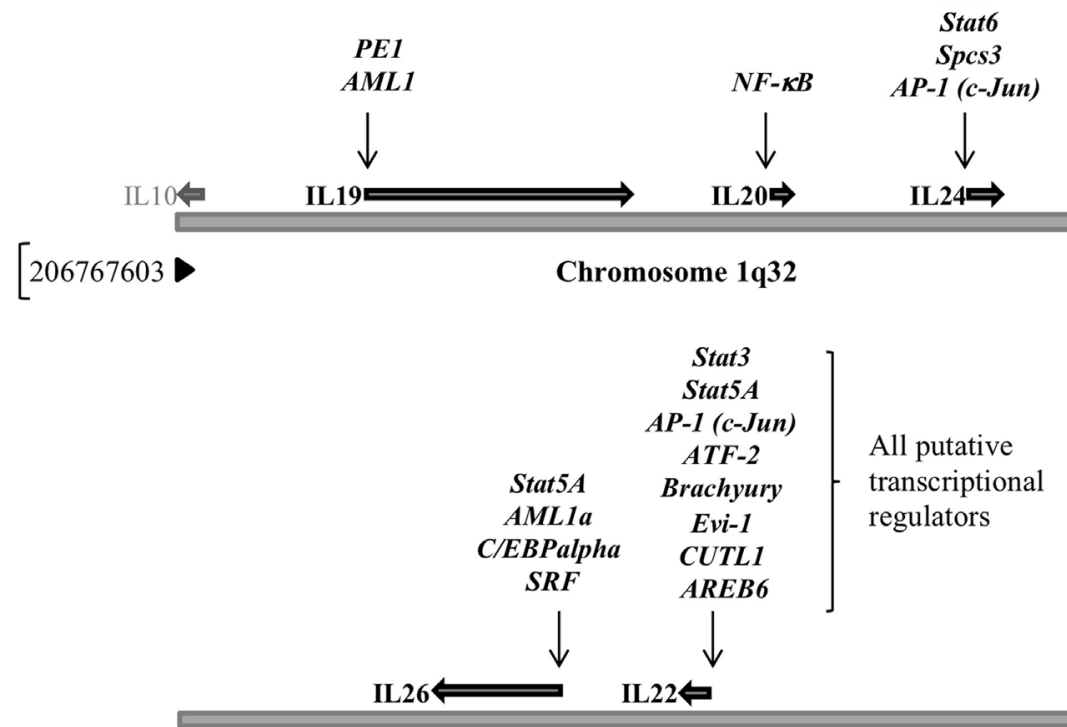

$[68154770$

Chromosome 12q16

B

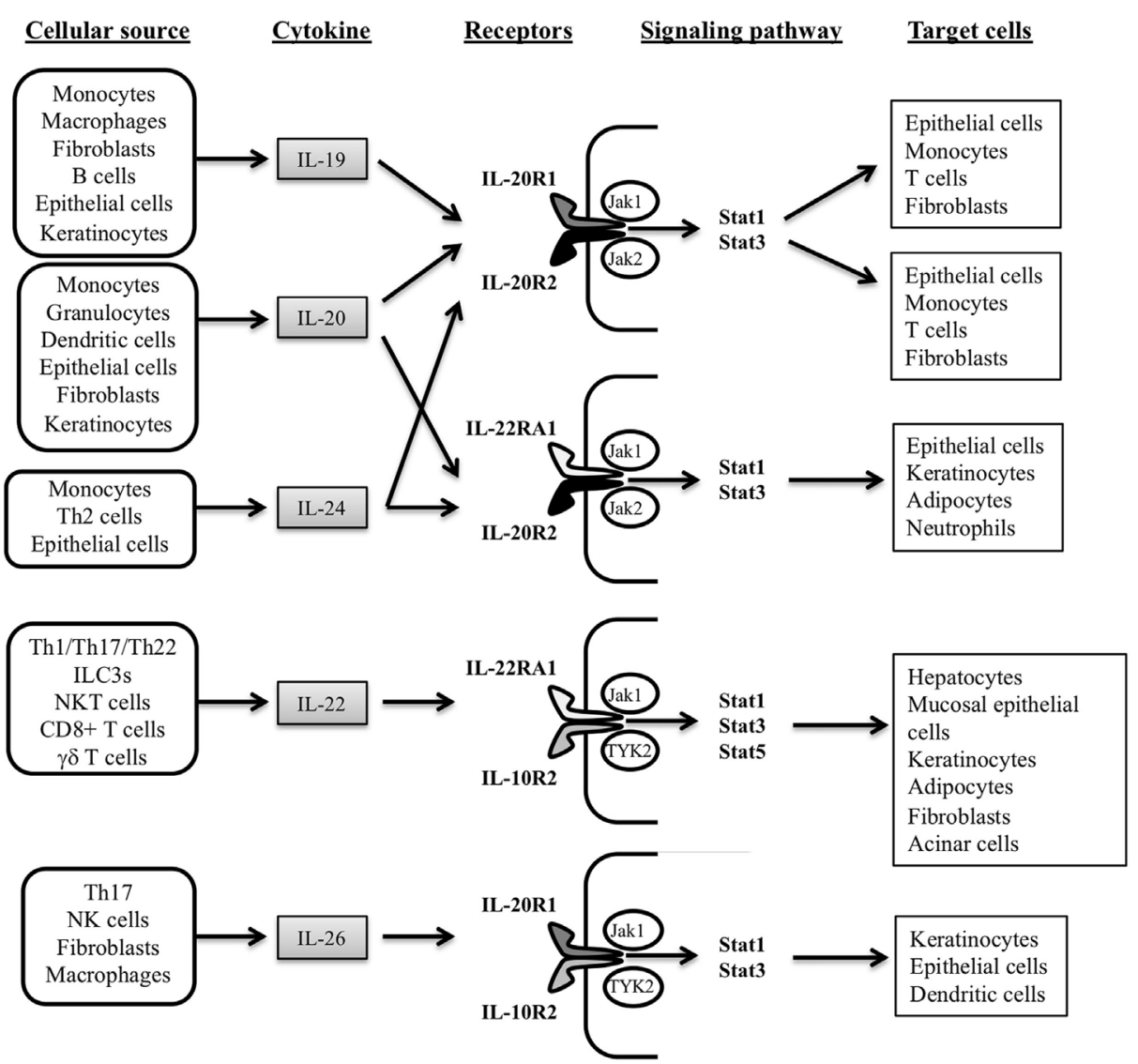

FIGURE 1 | (A) Genomic location for IL-20 subfamily of cytokines genes (chromosomes 1q32 and 12q16) and their transcriptional regulators. Note that for IL-22 and IL-26 putative regulators are provided (Human Gene Database, Weizmann Institute of Science, https://genecards.weizmann.ac.il/v3). (B) Cellular sources, receptors, signaling pathways activated and target cells of the IL-20 subfamily of cytokines. 
TABLE 1 | Roles of interleukin (IL)-20 subfamily cytokine members in liver diseases.

\begin{tabular}{|c|c|c|c|}
\hline Liver condition & $\begin{array}{l}\text { IL-20 cytokine family } \\
\text { member involved }\end{array}$ & Role & Reference \\
\hline \multirow[t]{5}{*}{ HBV } & $\mathrm{IL}-22$ & Downregulation of viral proteins & $(77)$ \\
\hline & & Promotion of cell proliferation, neutrophil recruitment, induction of chemokine production & (78) \\
\hline & & Induction of liver progenitor cells & (79) \\
\hline & & Chronic liver inflammation and fibrosis & (80) \\
\hline & & Proinflammatory & $(81)$ \\
\hline \multirow[t]{3}{*}{$\mathrm{HCV}$} & $\mathrm{IL}-22$ & Pathological & $(82,83)$ \\
\hline & & Hepatoprotective & $(84,85)$ \\
\hline & $\mathrm{IL}-26$ & Induction of antiviral state and improvement of killing activity by NK cells & $(76)$ \\
\hline \multirow[t]{3}{*}{ ALD } & IL-22 & Correlation with liver damage progression & (86) \\
\hline & & Good prognostic marker & $(87)$ \\
\hline & & Hepatoprotective & $(61,62,88,89)$ \\
\hline \multirow[t]{3}{*}{ NAFLD/NASH } & IL-20 & Progression of hepatic insulin resistance, regulation of lipid metabolism & $(56,65,90)$ \\
\hline & IL-22 & Regulation of lipid metabolism and inflammation & $(56,65,91,92)$ \\
\hline & $\mathrm{IL}-24$ & Regulation of lipid metabolism & $(56,65)$ \\
\hline \multirow[t]{4}{*}{$\mathrm{HCC}$} & $\mathrm{IL}-22$ & Promoter of tumor growth & $(93,94)$ \\
\hline & & Negative prognostic marker & (95) \\
\hline & IL-24 & Inhibition of cell growth & (96) \\
\hline & $\mathrm{IL}-26$ & Upregulation of NK anti-tumor activity & $(75)$ \\
\hline Liver inflammation & IL-19, IL-20, IL-22, IL-24 & Protective during liver inflammation & $(3,43,57)$ \\
\hline \multirow[t]{2}{*}{ Liver fibrosis } & $\mathrm{IL}-22$ & Amelioration of liver fibrosis & $(58,59,97)$ \\
\hline & & Predictor of severity (cirrhosis) & $(60)$ \\
\hline $\begin{array}{l}\text { Salmonella typhimurium } \\
\text { infection }\end{array}$ & IL-24 & Resolution improvement & $(71)$ \\
\hline
\end{tabular}

HBV, hepatitis B virus; HCV, hepatitis C virus; ALD, alcoholic liver disease; NAFLD/NASH, non-alcoholic fatty liver disease/non-alcoholic steatohepatitis; HCC, hepatocellular carcinoma.

scenes for different functions of IL-22 (102). More studies are needed to shed light on the IL-22 function in liver fibrosis, but this cytokine may be considered a therapeutic opportunity for future clinical management of liver disease.

Another IL-20 family member implicated in HCV infection is IL-26. This cytokine is overexpressed in serum when HCV infection occurs, and it is detected in liver lesions in chronic infection, particularly in patients with severe liver inflammation. As previously indicated, IL-26 boosts NK cell response to HCV challenge through the upregulation of tumor necrosis factor (TNF)-related apoptosis-inducing ligand (TRAIL) expression in the membrane surface of NK cells (75). Therefore, IL-26 has been proposed as a marker of inflammation in chronic $\mathrm{HCV}$ infection.

\section{IL-20 CYTOKINE FAMILY IN ALD}

Alcoholic liver disease comprises different categories of liver alterations, from liver steatosis to cirrhosis or cancer. In this context, alcohol consumption induces hepatotoxicity through intermediaries of ethanol metabolism, or by generating different mediators of the inflammatory response, like products of the oxidative stress response or proinflammatory cytokines secreted by liver Kupffer cells, such as TNF- $\alpha$ (103). Serum concentrations of both IL-17 cytokine protein isoforms, together with IL-22 levels, have been proposed as correlates of liver damage progression in ALD (86). Moreover, high-IL-22 levels seem to be a good prognostic marker (87). Liu et al. also describe an increase of IL-22 cytokine levels in alcoholic hepatitis patients, produced by macrophage in vitro, suggesting that the cytokine may have a hepatoprotective function (89). The authors also show an improvement in hepatocyte function and survival from ethanol-induced cell death when exposed to IL-22. Moreover, in a murine binge-drinking model, alcoholic liver injury is improved after treatment with IL-22 recombinant protein (88).

As both inflammation and hepatocyte damage are the main reasons for ALD, combined anti-inflammatory plus hepatoprotective therapy could hold promise for clinical management. At the time of writing, two different clinical trials on alcoholic hepatitis disease were in the recruitment phase (NCT01918462 and NCT02655510). Both trials implicate IL-22 in alcoholic hepatitis, with the first studying its biological effects in the disease and the second aiming to use recombinant human IL-22 to take advantage of the anti-steatotic and anti-apoptotic functions of this cytokine. These two pioneering clinical approaches may usher in new opportunities for handling ALD.

\section{IL-20 CYTOKINE FAMILY IN NON-ALD}

Non-alcoholic fatty liver disease (NAFLD) comprises a range of pathologies, from steatosis to non-alcoholic steatohepatitis (NASH). The mechanisms underlying this aggravation remain undefined, but a title role has been given to the innate immunity, inflammatory cytokines (85), and commensal microbiota (104). The protective role of the intestinal mucus coat has been analyzed 
in a murine model of fatty liver disease [high-fat diet (HFD)]. The absence of mucin-2 (muc2) in muc2-deficient HFD-fed mice causes the activation of the mucosal immune system resulting in higher plasmatic and intestinal levels of IL-22, with a role regulating lipid metabolism and inflammation in the liver and adipose tissue $(65,91,92)$.

In this line, investigators have detected high levels of Th22 cells in the liver tissue of IL-17-deficient mice, inferring a protective role during NASH progression (105). Regarding these Th cell populations, Rolla et al. point to the Th17/Th22 offset as a very important consideration when assessing NASH.

Increased IL-20 levels are present in visceral adipose tissue of NASH-diagnosed patients, and they are considered a target for miR-26a. This would induce a reduction in the expression of IL-20 cytokine (90). Estep et al. have studied IL-20 receptors as well as the cytokine itself, observing that IL-20RA is located in pericellular areas of fibrotic zones and that the expression of IL-20RB is also upregulated in NASH patients. This proinflammatory cytokine signals through STAT3 transcription factor, also activating the downstream IL-22 or IL-10 signaling pathway. STAT3 has been directly implicated in the progression of hepatic insulin resistance and its polymorphisms linked to NAFLD advancement $(106,107)$, so it could be a potential objective for modulating cytokine response during NAFLD development.

\section{IL-20 CYTOKINE FAMILY IN THE PROGRESSION OF HEPATOCELLULAR CARCINOMA}

Hepatocellular carcinoma (HCC) is the most frequent liver cancer variant, with incidence increasing every year. IL-22 is a wellestablished hepatoprotective cytokine; it promotes liver healing and tissue repair, preventing cellular apoptosis (62). It has a dual role in the control of liver disease, with new evidence showing that it participates in controlling viral and alcohol-induced HCC (108). Nonetheless, IL-22 can also promote tumor growth both in vitro and ex vivo $(93,94)$, and its levels are increased in patients with hepatocellular carcinoma (95). In a mouse model of HCC, metformin has been shown to reduce tumor growth and to inhibit the IL-22 signaling pathway (109). These data suggest that IL-22 might enhance liver tissue susceptibility to HCC development. Thus, although these results have been obtained from the animal model, clinicians must consider the risk of developing liver cancer when making therapeutic decisions for patients with hepatic disease in the future.

Interleukin-24 has been shown to inhibit HCC cells metastasis (96). This cytokine has been recently described to be regulated by the onco-microRNA miT-203a-3p.1. This microRNA controls IL-24 expression, and its inhibition can reverse HCC cell

\section{REFERENCES}

1. Pestka S, Krause CD, Sarkar D, Walter MR, Shi Y, Fisher PB. Interleukin-10 and related cytokines and receptors. Annu Rev Immunol (2004) 22:929-79. doi:10.1146/annurev.immunol.22.012703.104622

2. Wolk K, Kunz S, Witte E, Friedrich M, Asadullah K, Sabat R. IL-22 increases the innate immunity of tissues. Immunity (2004) 21:241-54. doi:10.1016/j. immuni.2004.07.007 proliferation and metastasis (110). In another cellular context, IL-24 acts synergistically with Notch pathway inhibitors in reducing tumor cell invasion and migration of HepG2 liver cancer cell line (111). In combination, the Notch pathway, miRNA miT203a-3p.1, and IL-24 can be now considered possible therapeutic objectives in HCC management.

An in vitro anti-tumor effect has also been described for IL-26 due to the fact that NK cell-specific cytotoxicity against the hepatocellular carcinoma line $\mathrm{HuH7.5}$ is highly upregulated in the presence of IL-26 (75). The induction mechanisms for this upregulation depend on the overexpression of the TRAIL receptor in NK cells, which contributes to their cytotoxic activity.

\section{FUTURE DIRECTIONS AND CONCLUDING REMARKS}

The different cytokine members of the IL-20 subfamily perform an array of antiviral, anti-apoptotic, progenitor cell-generating, and lipid metabolism regulator functions as a part of liver homeostasis in viral hepatitis, ALD, NASH, and hepatocarcinoma. The protective role of this family preventing tissue damage and inflammation makes these cytokines crucial targets for liver disease therapy: (a) IL-22 has shown both pathological and hepatoprotective roles, so IL-22-IL-22R1 therapeutic possibilities seem to depend on the presence of different inflammatory conditions, which may either require the activation of this pathway or justify its inhibition; (b) IL-19, IL-20, and IL-24 have a key role in the wound healing process of fibrogenesis in the liver, and IL-22 in the angiogenesis and neo-vascularization events; (c) IL-26 can be considered a promising scope in infectious diseases management, given the antimicrobial and antiviral function already reported for this cytokine.

Our review hints at a wide and still unexplored area of research on the close interactions between ILs and the pathophysiology of liver diseases. Taking account of the number of processes in which IL-20 subfamily of cytokines is actively participating, therapeutic interventions with these cytokines stand out as a vast and promising area of study.

\section{AUTHOR CONTRIBUTIONS}

EC and RF equally contributed to the design and writing of the manuscript.

\section{FUNDING}

This work has been partially funded by grants PI16/0967 from Instituto de Salud Carlos III, Madrid, Spain, PROMETEO/2016/ 001 from Generalitat Valenciana, Valencia, Spain, and FEDER funds, EU.

3. Ouyang W, Rutz S, Crellin NK, Valdez PA, Hymowitz SG. Regulation and functions of the IL-10 family of cytokines in inflammation and disease. Annu Rev Immunol (2011) 29:71-109. doi:10.1146/annurev-immunol-031210-101312

4. Rutz S, Wang X, Ouyang W. The IL-20 subfamily of cytokines-from host defence to tissue homeostasis. Nat Rev Immunol (2014) 14:783-95. doi:10.1038/nri3766

5. Dudakov JA, Hanash AM, Van Den Brink MR. Interleukin-22: immunobiology and pathology. Annu Rev Immunol (2015) 33:747-85. doi:10.1146/ annurev-immunol-032414-112123 
6. Sabat R, Wallace E, Endesfelder S, Wolk K. IL-19 and IL-20: two novel cytokines with importance in inflammatory diseases. Expert Opin Ther Targets (2007) 11:601-12. doi:10.1517/14728222.11.5.601

7. Jones EA, Flavell RA. Distal enhancer elements transcribe intergenic RNA in the IL-10 family gene cluster. J Immunol (2005) 175:7437-46. doi:10.4049/ jimmunol.175.11.7437

8. Dumoutier L, Van Roost E, Ameye G, Michaux L, Renauld JC. IL-TIF/IL-22: genomic organization and mapping of the human and mouse genes. Genes Immun (2000) 1:488-94. doi:10.1038/sj.gene.6363716

9. Knappe A, Hor S, Wittmann S, Fickenscher H. Induction of a novel cellular homolog of interleukin-10, AK155, by transformation of T lymphocytes with herpesvirus saimiri. J Virol (2000) 74:3881-7. doi:10.1128/ JVI.74.8.3881-3887.2000

10. Chen PJ, Wei CC, Wang C, Chen FW, Hsu YH, Chang MS. Promoter analysis of interleukin 19. Biochem Biophys Res Commun (2006) 344:713-20. doi:10.1016/j.bbrc.2006.03.200

11. Otkjaer K, Kragballe K, Johansen C, Funding AT, Just H, Jensen UB, et al. IL-20 gene expression is induced by IL-1beta through mitogen-activated protein kinase and NF-kappaB-dependent mechanisms. J Invest Dermatol (2007) 127:1326-36. doi:10.1038/sj.jid.5700713

12. Hunt DW, Boivin WA, Fairley LA, Jovanovic MM, King DE, Salmon RA, et al. Ultraviolet B light stimulates interleukin-20 expression by human epithelial keratinocytes. Photochem Photobiol (2006) 82:1292-300. doi:10.1562/2005-08-31-RA-668

13. Sahoo A, Lee CG, Jash A, Son JS, Kim G, Kwon HK, et al. Stat6 and c-Jun mediate Th2 cell-specific IL-24 gene expression. J Immunol (2011) 186:4098-109. doi:10.4049/jimmunol.1002620

14. Kotenko SV, Izotova LS, Mirochnitchenko OV, Esterova E, Dickensheets H, Donnelly RP, et al. Identification of the functional interleukin-22 (IL-22) receptor complex: the IL-10R2 chain (IL-10Rbeta) is a common chain of both the IL-10 and IL-22 (IL-10-related T cell-derived inducible factor, IL-TIF) receptor complexes. J Biol Chem (2001) 276:2725-32. doi:10.1074/ jbc.M007837200

15. Parrish-Novak J, Xu W, Brender T, Yao L, Jones C, West J, et al. Interleukins 19, 20, and 24 signal through two distinct receptor complexes. Differences in receptor-ligand interactions mediate unique biological functions. J Biol Chem (2002) 277:47517-23. doi:10.1074/jbc.M205114200

16. Wang M, Tan Z, Zhang R, Kotenko SV, Liang P. Interleukin 24 (MDA-7/ MOB-5) signals through two heterodimeric receptors, IL-22R1/IL-20R2 and IL-20R1/IL-20R2. J Biol Chem (2002) 277:7341-7. doi:10.1074/jbc. M106043200

17. Sheikh F, Baurin VV, Lewis-Antes A, Shah NK, Smirnov SV, Anantha S, et al. Cutting edge: IL-26 signals through a novel receptor complex composed of IL-20 receptor 1 and IL-10 receptor 2. J Immunol (2004) 172:2006-10. doi:10.4049/jimmunol.172.4.2006

18. Garn H, Schmidt A, Grau V, Stumpf S, Kaufmann A, Becker M, et al. IL-24 is expressed by rat and human macrophages. Immunobiology (2002) 205: 321-34. doi:10.1078/0171-2985-00135

19. Poindexter NJ, Walch ET, Chada S, Grimm EA. Cytokine induction of interleukin-24 in human peripheral blood mononuclear cells. J Leukoc Biol (2005) 78:745-52. doi:10.1189/jlb.0205116

20. Wang F, Lee E, Lowes MA, Haider AS, Fuentes-Duculan J, Abello MV, et al. Prominent production of IL-20 by CD68+/CD11c+ myeloid-derived cells in psoriasis: gene regulation and cellular effects. J Invest Dermatol (2006) 126:1590-9. doi:10.1038/sj.jid.5700310

21. Gallagher G, Dickensheets H, Eskdale J, Izotova LS, Mirochnitchenko OV, Peat JD, et al. Cloning, expression and initial characterization of interleukin19 (IL-19), a novel homologue of human interleukin-10 (IL-10). Genes Immun (2000) 1:442-50. doi:10.1038/sj.gene.6363714

22. Wolk K, Kunz S, Asadullah K, Sabat R. Cutting edge: immune cells as sources and targets of the IL-10 family members? J Immunol (2002) 168:5397-402. doi:10.4049/jimmunol.168.11.5397

23. Wolk K, Witte K, Witte E, Proesch S, Schulze-Tanzil G, Nasilowska K, et al. Maturing dendritic cells are an important source of IL-29 and IL-20 that may cooperatively increase the innate immunity of keratinocytes. J Leukoc Biol (2008) 83:1181-93. doi:10.1189/jlb.0807525

24. Schaefer G, Venkataraman C, Schindler U. Cutting edge: FISP (IL-4-induced secreted protein), a novel cytokine-like molecule secreted by Th2 cells. J Immunol (2001) 166:5859-63. doi:10.4049/jimmunol.166.10.5859
25. Gurney AL. IL-22, a Th1 cytokine that targets the pancreas and select other peripheral tissues. Int Immunopharmacol (2004) 4:669-77. doi:10.1016/j. intimp.2004.01.016

26. Wilson NJ, Boniface K, Chan JR, Mckenzie BS, Blumenschein WM, Mattson JD, et al. Development, cytokine profile and function of human interleukin 17-producing helper T cells. Nat Immunol (2007) 8:950-7. doi:10.1038/ni1497

27. Manel N, Unutmaz D, Littman DR. The differentiation of human T(H)-17 cells requires transforming growth factor-beta and induction of the nuclear receptor RORgammat. Nat Immunol (2008) 9:641-9. doi:10.1038/ni.1610

28. Ouyang W, Kolls JK, Zheng Y. The biological functions of T helper 17 cell effector cytokines in inflammation. Immunity (2008) 28:454-67. doi:10.1016/j.immuni.2008.03.004

29. Colonna M. Interleukin-22-producing natural killer cells and lymphoid tissue inducer-like cells in mucosal immunity. Immunity (2009) 31:15-23. doi:10.1016/j.immuni.2009.06.008

30. Cupedo T, Crellin NK, Papazian N, Rombouts EJ, Weijer K, Grogan JL, et al. Human fetal lymphoid tissue-inducer cells are interleukin 17-producing precursors to RORC+ CD127+ natural killer-like cells. Nat Immunol (2009) 10:66-74. doi:10.1038/ni.1668

31. Duhen T, Geiger R, Jarrossay D, Lanzavecchia A, Sallusto F. Production of interleukin 22 but not interleukin 17 by a subset of human skin-homing memory T cells. Nat Immunol (2009) 10:857-63. doi:10.1038/ni.1767

32. Eyerich S, Eyerich K, Pennino D, Carbone T, Nasorri F, Pallotta S, et al. Th22 cells represent a distinct human $\mathrm{T}$ cell subset involved in epidermal immunity and remodeling. J Clin Invest (2009) 119:3573-85. doi:10.1172/ JCI40202

33. Martin B, Hirota K, Cua DJ, Stockinger B, Veldhoen M. Interleukin17-producing gammadelta $\mathrm{T}$ cells selectively expand in response to pathogen products and environmental signals. Immunity (2009) 31:321-30. doi:10.1016/ j.immuni.2009.06.020

34. Sutton CE, Lalor SJ, Sweeney CM, Brereton CF, Lavelle EC, Mills KH. Interleukin-1 and IL-23 induce innate IL-17 production from gammadelta $\mathrm{T}$ cells, amplifying Th17 responses and autoimmunity. Immunity (2009) 31:331-41. doi:10.1016/j.immuni.2009.08.001

35. Takatori H, Kanno Y, Watford WT, Tato CM, Weiss G, Ivanov II, et al. Lymphoid tissue inducer-like cells are an innate source of IL-17 and IL-22. J Exp Med (2009) 206:35-41. doi:10.1084/jem.20072713

36. Trifari S, Kaplan CD, Tran EH, Crellin NK, Spits H. Identification of a human helper $\mathrm{T}$ cell population that has abundant production of interleukin 22 and is distinct from $\mathrm{T}(\mathrm{H})-17, \mathrm{~T}(\mathrm{H}) 1$ and $\mathrm{T}(\mathrm{H}) 2$ cells. Nat Immunol (2009) 10:864-71. doi:10.1038/ni.1770

37. Wang Z, Wang M, Lazo JS, Carr BI. Identification of epidermal growth factor receptor as a target of Cdc25A protein phosphatase. J Biol Chem (2002) 277:19470-5. doi:10.1074/jbc.M201097200

38. Goto M, Murakawa M, Kadoshima-Yamaoka K, Tanaka Y, Nagahira K, Fukuda Y, et al. Murine NKT cells produce Th17 cytokine interleukin-22. Cell Immunol (2009) 254:81-4. doi:10.1016/j.cellimm.2008.10.002

39. Moreira-Teixeira L, Resende M, Coffre M, Devergne O, Herbeuval JP, Hermine O, et al. Proinflammatory environment dictates the IL-17-producing capacity of human invariant NKT cells. J Immunol (2011) 186:5758-65. doi:10.4049/jimmunol.1003043

40. Paget C, Ivanov S, Fontaine J, Renneson J, Blanc F, Pichavant M, et al. Interleukin-22 is produced by invariant natural killer $\mathrm{T}$ lymphocytes during influenza A virus infection: potential role in protection against lung epithelial damages. J Biol Chem (2012) 287:8816-29. doi:10.1074/jbc. M111.304758

41. Mabuchi T, Takekoshi T, Hwang ST. Epidermal CCR6+ gammadelta T cells are major producers of IL-22 and IL-17 in a murine model of psoriasiform dermatitis. J Immunol (2011) 187:5026-31. doi:10.4049/jimmunol.1101817

42. Mielke LA, Jones SA, Raverdeau M, Higgs R, Stefanska A, Groom JR, et al. Retinoic acid expression associates with enhanced IL-22 production by gammadelta $\mathrm{T}$ cells and innate lymphoid cells and attenuation of intestinal inflammation. J Exp Med (2013) 210:1117-24. doi:10.1084/jem.20121588

43. Yi P, Liang Y, Yuan DMK, Jie Z, Kwota Z, Chen Y, et al. A tightly regulated IL-22 response maintains immune functions and homeostasis in systemic viral infection. Sci Rep (2017) 7:3857. doi:10.1038/s41598-017-04260-0

44. Sa SM, Valdez PA, Wu J, Jung K, Zhong F, Hall L, et al. The effects of IL-20 subfamily cytokines on reconstituted human epidermis suggest potential 
roles in cutaneous innate defense and pathogenic adaptive immunity in psoriasis. J Immunol (2007) 178:2229-40. doi:10.4049/jimmunol.178.11.7487-a

45. Aujla SJ, Chan YR, Zheng M, Fei M, Askew DJ, Pociask DA, et al. IL-22 mediates mucosal host defense against Gram-negative bacterial pneumonia. Nat Med (2008) 14:275-81. doi:10.1038/nm1710

46. Huang F, Wachi S, Thai P, Loukoianov A, Tan KH, Forteza RM, et al. Potentiation of IL-19 expression in airway epithelia by IL-17A and IL-4/ IL-13: important implications in asthma. J Allergy Clin Immunol (2008) 121:1415-21, 1421.e1-3. doi:10.1016/j.jaci.2008.04.016

47. Yano S, Banno T, Walsh R, Blumenberg M. Transcriptional responses of human epidermal keratinocytes to cytokine interleukin-1. JCell Physiol (2008) 214:1-13. doi:10.1002/jcp.21300

48. Wolk K, Witte E, Warszawska K, Schulze-Tanzil G, Witte K, Philipp S, et al. The Th17 cytokine IL-22 induces IL-20 production in keratinocytes: a novel immunological cascade with potential relevance in psoriasis. Eur J Immunol (2009) 39:3570-81. doi:10.1002/eji.200939687

49. Dumoutier L, Van Roost E, Colau D, Renauld JC. Human interleukin10-related T cell-derived inducible factor: molecular cloning and functional characterization as an hepatocyte-stimulating factor. Proc Natl Acad Sci U S A (2000) 97:10144-9. doi:10.1073/pnas.170291697

50. Aggarwal S, Xie MH, Maruoka M, Foster J, Gurney AL. Acinar cells of the pancreas are a target of interleukin-22. J Interferon Cytokine Res (2001) 21:1047-53. doi:10.1089/107999001317205178

51. Nagalakshmi ML, Rascle A, Zurawski S, Menon S, De Waal Malefyt R. Interleukin-22 activates STAT3 and induces IL-10 by colon epithelial cells. Int Immunopharmacol (2004) 4:679-91. doi:10.1016/j.intimp.2004.01.008

52. Andoh A, Zhang Z, Inatomi O, Fujino S, Deguchi Y, Araki Y, et al. Interleukin-22, a member of the IL-10 subfamily, induces inflammatory responses in colonic subepithelial myofibroblasts. Gastroenterology (2005) 129:969-84. doi:10.1053/j.gastro.2005.06.071

53. Pickert G, Neufert C, Leppkes M, Zheng Y, Wittkopf N, Warntjen M, et al. STAT3 links IL-22 signaling in intestinal epithelial cells to mucosal wound healing. J Exp Med (2009) 206:1465-72. doi:10.1084/jem.20082683

54. Kunz S, Wolk K, Witte E, Witte K, Doecke WD, Volk HD, et al. Interleukin (IL)-19, IL-20 and IL-24 are produced by and act on keratinocytes and are distinct from classical ILs. Exp Dermatol (2006) 15:991-1004. doi:10.1111/ j.1600-0625.2006.00516.x

55. Wang Z, Yang L, Jiang Y, Ling ZQ, Li Z, Cheng Y, et al. High fat diet induces formation of spontaneous liposarcoma in mouse adipose tissue with overexpression of interleukin 22. PLoS One (2011) 6:e23737. doi:10.1371/journal. pone. 0023737

56. Wang C, Chen Z, Li S, Zhang Y, Jia S, Li J, et al. Hepatic overexpression of ATP synthase beta subunit activates PI3K/Akt pathway to ameliorate hyperglycemia of diabetic mice. Diabetes (2014) 63:947-59. doi:10.2337/db13-1096

57. Kong X, Feng D, Wang H, Hong F, Bertola A, Wang FS, et al. Interleukin-22 induces hepatic stellate cell senescence and restricts liver fibrosis in mice. Hepatology (2012) 56:1150-9. doi:10.1002/hep.25744

58. Meng F, Wang K, Aoyama T, Grivennikov SI, Paik Y, Scholten D, et al. Interleukin-17 signaling in inflammatory, Kupffer cells, and hepatic stellate cells exacerbates liver fibrosis in mice. Gastroenterology (2012) 143 (765-776):e763. doi:10.1053/j.gastro.2012.05.049

59. Hu BL, Shi C, Lei RE, Lu DH, Luo W, Qin SY, et al. Interleukin-22 ameliorates liver fibrosis through miR-200a/beta-catenin. Sci Rep (2016) 6:36436. doi:10.1038/srep36436

60. Kronenberger B, Rudloff I, Bachmann M, Brunner F, Kapper L, Filmann N, et al. Interleukin-22 predicts severity and death in advanced liver cirrhosis: a prospective cohort study. BMC Med (2012) 10:102. doi:10.1186/17417015-10-102

61. Kong X, Feng D, Mathews S, Gao B. Hepatoprotective and anti-fibrotic functions of interleukin-22: therapeutic potential for the treatment of alcoholic liver disease. J Gastroenterol Hepatol (2013) 28(Suppl 1):56-60. doi:10.1111/ jgh. 12032

62. Pan CX, Tang J, Wang XY, Wu FR, Ge JF, Chen FH. Role of interleukin-22 in liver diseases. Inflamm Res (2014) 63:519-25. doi:10.1007/s00011-014-0727-3

63. Nakamoto N, Amiya T, Aoki R, Taniki N, Koda Y, Miyamoto K, et al. Commensal Lactobacillus controls immune tolerance during acute liver injury in mice. Cell Rep (2017) 21:1215-26. doi:10.1016/j.celrep.2017.10.022

64. Wegenka UM, Dikopoulos N, Reimann J, Adler G, Wahl C. The murine liver is a potential target organ for IL-19, IL-20 and IL-24: type I interferons and LPS regulate the expression of IL-20R2. J Hepatol (2007) 46:257-65. doi:10.1016/j.jhep.2006.08.009

65. Wang X, Ota N, Manzanillo P, Kates L, Zavala-Solorio J, Eidenschenk C, et al. Interleukin-22 alleviates metabolic disorders and restores mucosal immunity in diabetes. Nature (2014) 514:237-41. doi:10.1038/nature13564

66. Bao P, Kodra A, Tomic-Canic M, Golinko MS, Ehrlich HP, Brem H. The role of vascular endothelial growth factor in wound healing. I Surg Res (2009) 153:347-58. doi:10.1016/j.jss.2008.04.023

67. Poindexter NJ, Williams RR, Powis G, Jen E, Caudle AS, Chada S, et al. IL-24 is expressed during wound repair and inhibits TGFalpha-induced migration and proliferation of keratinocytes. Exp Dermatol (2010) 19:714-22. doi:10.1111/j.1600-0625.2010.01077.x

68. Mcgee HM, Schmidt BA, Booth CJ, Yancopoulos GD, Valenzuela DM, Murphy AJ, et al. IL-22 promotes fibroblast-mediated wound repair in the skin. J Invest Dermatol (2013) 133:1321-9. doi:10.1038/jid.2012.463

69. Sun DP, Yeh CH, So E, Wang LY, Wei TS, Chang MS, et al. Interleukin (IL)-19 promoted skin wound healing by increasing fibroblast keratinocyte growth factor expression. Cytokine (2013) 62:360-8. doi:10.1016/j.cyto.2013.03.017

70. Bataller R, Schwabe RF, Choi YH, Yang L, Paik YH, Lindquist J, et al. NADPH oxidase signal transduces angiotensin II in hepatic stellate cells and is critical in hepatic fibrosis. J Clin Invest (2003) 112:1383-94. doi:10.1172/JCI18212

71. Ma Y, Chen H, Wang Q, Luo F, Yan J, Zhang XL. IL-24 protects against Salmonella typhimurium infection by stimulating early neutrophil Th1 cytokine production, which in turn activates CD8+ T cells. Eur J Immunol (2009) 39:3357-68. doi:10.1002/eji.200939678

72. Meller S, Di Domizio J, Voo KS, Friedrich HC, Chamilos G, Ganguly D, et al. $\mathrm{T}(\mathrm{H}) 17$ cells promote microbial killing and innate immune sensing of DNA via interleukin 26. Nat Immunol (2015) 16:970-9. doi:10.1038/ni.3211

73. Stephen-Victor E, Fickenscher H, Bayry J. IL-26: an emerging proinflammatory member of the IL-10 cytokine family with multifaceted actions in antiviral, antimicrobial, and autoimmune responses. PLoS Pathog (2016) 12:e1005624. doi:10.1371/journal.ppat.1005624

74. Ohnuma K, Hatano R, Aune TM, Otsuka H, Iwata S, Dang NH, et al. Regulation of pulmonary graft-versus-host disease by IL-26+CD26+CD4 T lymphocytes. J Immunol (2015) 194:3697-712. doi:10.4049/jimmunol.1402785

75. Miot C, Beaumont E, Duluc D, Le Guillou-Guillemette H, Preisser L, Garo E, et al. IL-26 is overexpressed in chronically HCV-infected patients and enhances TRAIL-mediated cytotoxicity and interferon production by human NK cells. Gut (2015) 64:1466-75. doi:10.1136/gutjnl-2013-306604

76. Hor S, Pirzer H, Dumoutier L, Bauer F, Wittmann S, Sticht H, et al. The T-cell lymphokine interleukin-26 targets epithelial cells through the interleukin20 receptor 1 and interleukin-10 receptor 2 chains. J Biol Chem (2004) 279:33343-51. doi:10.1074/jbc.M405000200

77. Jie Z, Liang Y, Yi P, Tang H, Soong L, Cong Y, et al. Retinoic acid regulates immune responses by promoting IL-22 and modulating S100 proteins in viral hepatitis. J Immunol (2017) 198:3448-60. doi:10.4049/jimmunol.1601891

78. Cobleigh MA, Robek MD. Protective and pathological properties of IL-22 in liver disease: implications for viral hepatitis. Am J Pathol (2013) 182:21-8. doi:10.1016/j.ajpath.2012.08.043

79. Feng D, Kong X, Weng H, Park O, Wang H, Dooley S, et al. Interleukin-22 promotes proliferation of liver stem/progenitor cells in mice and patients with chronic hepatitis B virus infection. Gastroenterology (2012) 143:188-98. e7. doi:10.1053/j.gastro.2012.03.044

80. Zhao J, Zhang Z, Luan Y, Zou Z, Sun Y, Li Y, et al. Pathological functions of interleukin-22 in chronic liver inflammation and fibrosis with hepatitis $B$ virus infection by promoting T helper 17 cell recruitment. Hepatology (2014) 59:1331-42. doi:10.1002/hep.26916

81. Zhang Y, Cobleigh MA, Lian JQ, Huang CX, Booth CJ, Bai XF, et al. A proinflammatory role for interleukin-22 in the immune response to hepatitis B virus. Gastroenterology (2011) 141:1897-906. doi:10.1053/j.gastro. 011.06 .051

82. Wu LY, Liu S, Liu Y, Guo C, Li H, Li W, et al. Up-regulation of interleukin-22 mediates liver fibrosis via activating hepatic stellate cells in patients with hepatitis C. Clin Immunol (2015) 158:77-87. doi:10.1016/j.clim.2015.03.003

83. Gao Y, Ren H, Meng F, Li J, Cheung E, Li H, et al. Pathological roles of interleukin-22 in the development of recurrent hepatitis $\mathrm{C}$ after liver transplantation. PLoS One (2016) 11:e0154419. doi:10.1371/journal.pone.0154419

84. Sertorio M, Hou X, Carmo RF, Dessein H, Cabantous S, Abdelwahed M, et al. IL-22 and IL-22 binding protein (IL-22BP) regulate fibrosis and cirrhosis in 
hepatitis C virus and schistosome infections. Hepatology (2015) 61:1321-31. doi:10.1002/hep. 27629

85. Carmo RF, Cavalcanti MSM, Moura P. Role of Interleukin-22 in chronic liver injury. Cytokine (2017) 98:107-14. doi:10.1016/j.cyto.2016.08.023

86. Parfieniuk-Kowerda A, Swiderska M, Szulzyk T, Jaroszewicz J, Lapinski TW, Flisiak R. Serum concentrations of Th17-associated interleukins and autoimmune phenomena are associated with the degree of liver damage in alcoholic liver disease. J Gastrointestin Liver Dis (2017) 26:269-74. doi:10.15403/ jgld.2014.1121.263.pak

87. Stoy S, Sandahl TD, Dige AK, Agnholt J, Rasmussen TK, Gronbaek H, et al. Highest frequencies of interleukin-22-producing $\mathrm{T}$ helper cells in alcoholic hepatitis patients with a favourable short-term course. PLoS One (2013) 8:e55101. doi:10.1371/journal.pone.0055101

88. Ki SH, Park O, Zheng M, Morales-Ibanez O, Kolls JK, Bataller R, et al. Interleukin-22 treatment ameliorates alcoholic liver injury in a murine model of chronic-binge ethanol feeding: role of signal transducer and activator of transcription 3. Hepatology (2010) 52:1291-300. doi:10.1002/hep.23837

89. Liu Y, Verma VK, Malhi H, Gores GJ, Kamath PS, Sanyal A, et al. Lipopolysaccharide downregulates macrophage-derived IL-22 to modulate alcohol-induced hepatocyte cell death. Am J Physiol Cell Physiol (2017) 313:C305-13. doi:10.1152/ajpcell.00005.2017

90. Estep JM, Goodman Z, Sharma H, Younossi E, Elarainy H, Baranova A, et al. Adipocytokine expression associated with miRNA regulation and diagnosis of NASH in obese patients with NAFLD. Liver Int (2015) 35:1367-72. doi:10.1111/ liv. 12555

91. Yang L, Zhang Y, Wang L, Fan F, Zhu L, Li Z, et al. Amelioration of high fat diet induced liver lipogenesis and hepatic steatosis by interleukin-22. J Hepatol (2010) 53:339-47. doi:10.1016/j.jhep.2010.03.004

92. Hartmann P, Seebauer CT, Mazagova M, Horvath A, Wang L, Llorente C, et al. Deficiency of intestinal mucin-2 protects mice from diet-induced fatty liver disease and obesity. Am J Physiol Gastrointest Liver Physiol (2016) 310:G310-22. doi:10.1152/ajpgi.00094.2015

93. Radaeva S, Sun R, Pan HN, Hong F, Gao B. Interleukin 22 (IL-22) plays a protective role in T cell-mediated murine hepatitis: IL-22 is a survival factor for hepatocytes via STAT3 activation. Hepatology (2004) 39:1332-42. doi:10.1002/hep.20184

94. Jiang R, Tan Z, Deng L, Chen Y, Xia Y, Gao Y, et al. Interleukin-22 promotes human hepatocellular carcinoma by activation of STAT3. Hepatology (2011) 54:900-9. doi:10.1002/hep.24486

95. Waidmann O, Kronenberger B, Scheiermann P, Koberle V, Muhl H, Piiper A. Interleukin-22 serum levels are a negative prognostic indicator in patients with hepatocellular carcinoma. Hepatology (2014) 59:1207. doi:10.1002/ hep. 26528

96. Menezes ME, Bhatia S, Bhoopathi P, Das SK, Emdad L, Dasgupta S, et al. MDA-7/IL-24: multifunctional cancer killing cytokine. Adv Exp Med Biol (2014) 818:127-53. doi:10.1007/978-1-4471-6458-6_6

97. Guillot A, Hamdaoui N, Bizy A, Zoltani K, Souktani R, Zafrani ES, et al. Cannabinoid receptor 2 counteracts interleukin-17-induced immune and fibrogenic responses in mouse liver. Hepatology (2014) 59(1):296-306. doi:10.1002/hep. 26598

98. Dambacher J, Beigel F, Zitzmann K, Heeg MH, Goke B, Diepolder HM, et al. The role of interleukin-22 in hepatitis C virus infection. Cytokine (2008) 41:209-16. doi:10.1016/j.cyto.2007.11.016

99. Park O, Wang H, Weng H, Feigenbaum L, Li H, Yin S, et al. In vivo consequences of liver-specific interleukin-22 expression in mice: implications for human liver disease progression. Hepatology (2011) 54:252-61. doi:10.1002/ hep. 24339

100. Foster RG, Golden-Mason L, Rutebemberwa A, Rosen HR. Interleukin (IL)-17/IL-22-producing T cells enriched within the liver of patients with chronic hepatitis C viral (HCV) infection. Dig Dis Sci (2012) 57:381-9. doi:10.1007/s10620-011-1997-z

101. Wei X, Wang JP, Hao CQ, Yang XF, Wang LX, Huang CX, et al. notch signaling contributes to liver inflammation by regulation of interleukin22-producing cells in hepatitis B virus infection. Front Cell Infect Microbiol (2016) 6:132. doi:10.3389/fcimb.2016.00132

102. Gao W, Fan YC, Zhang JY, Zheng MH. Emerging role of interleukin 22 in hepatitis B virus infection: a double-edged sword. JClin Transl Hepatol (2013) 1:103-8. doi:10.14218/JCTH.2013.00013

103. Szabo G, Mandrekar P, Petrasek J, Catalano D. The unfolding web of innate immune dysregulation in alcoholic liver injury. Alcohol Clin Exp Res (2011) 35:782-6. doi:10.1111/j.1530-0277.2010.01398.x

104. Brandl K, Schnabl B. Intestinal microbiota and nonalcoholic steatohepatitis. Curr Opin Gastroenterol (2017) 33:128-33. doi:10.1097/MOG.0000000000 000349

105. Rolla S, Alchera E, Imarisio C, Bardina V, Valente G, Cappello P, et al. The balance between IL-17 and IL-22 produced by liver-infiltrating T-helper cells critically controls NASH development in mice. Clin Sci (Lond) (2016) 130:193-203. doi:10.1042/CS20150405

106. Sookoian S, Castano G, Gianotti TF, Gemma C, Rosselli MS, Pirola CJ. Genetic variants in STAT3 are associated with nonalcoholic fatty liver disease. Cytokine (2008) 44:201-6. doi:10.1016/j.cyto.2008.08.001

107. Zhang Y, Zhou B, Deng B, Zhang F, Wu J, Wang Y, et al. Amyloid-beta induces hepatic insulin resistance in vivo via JAK2. Diabetes (2013) 62:1159-66. doi: $10.2337 / \mathrm{db} 12-0670$

108. Saalim M, Resham S, Manzoor S, Ahmad H, Jaleel S, Ashraf J, et al. IL-22: a promising candidate to inhibit viral-induced liver disease progression and hepatocellular carcinoma. Tumour Biol (2016) 37:105-14. doi:10.1007/ s13277-015-4294-1

109. Zhao D, Long XD, Lu TF, Wang T, Zhang WW, Liu YX, et al. Metformin decreases IL-22 secretion to suppress tumor growth in an orthotopic mouse model of hepatocellular carcinoma. Int J Cancer (2015) 136:2556-65. doi:10.1002/ijc.29305

110. Huo W, Du M, Pan X, Zhu X, Gao Y, Li Z. miR-203a-3p.1 targets IL-24 to modulate hepatocellular carcinoma cell growth and metastasis. FEBS Open Bio (2017) 7:1085-91. doi:10.1002/2211-5463.12248

111. Han B, Liu SH, Guo WD, Zhang B, Wang JP, Cao YK, et al. Notch1 downregulation combined with interleukin-24 inhibits invasion and migration of hepatocellular carcinoma cells. World J Gastroenterol (2015) 21:9727-35. doi:10.3748/wjg.v21.i33.9727

Conflict of Interest Statement: The authors declare that the research was conducted in the absence of any commercial or financial relationships that could be construed as a potential conflict of interest.

Copyright ( 2018 Caparrós and Francés. This is an open-access article distributed under the terms of the Creative Commons Attribution License (CC BY). The use, distribution or reproduction in other forums is permitted, provided the original author(s) and the copyright owner are credited and that the original publication in this journal is cited, in accordance with accepted academic practice. No use, distribution or reproduction is permitted which does not comply with these terms. 